\title{
PENGARUH PROGRAM DIABETES SELF MANAGEMENT EDUCATION TERHADAP PENURUNAN KADAR GULA DARAH PASIEN DM TIPE 2 DI RSU ROYAL PRIMA MEDAN TAHUN 2019
}

\author{
Yusmar Christianto Zai ${ }^{1}$, Juwita Imelda Telaumbanua ${ }^{2}$, Monica Clara Siregar ${ }^{3}$, Kharisman \\ Bohalima $^{4}$, Karmila Br Kaban ${ }^{5}$ \\ Universitas Prima Indonesia, Fakultas Keperawatan dan Kebidanan, \\ Jl. Danau Singkarak Gg. Madrasah, Kelurahan Sei Agul Kecamatan Medan Barat
}

\begin{abstract}
Abstrak
DSME merupakan suatu proses pemberian pengetahuan pasien tentang manajemen diri untuk mengendalikan kadar glukosa darah dengan pengaturan diet, latihan fisik, serta terapi farmakologis sehingga penederita diabetes melitus dapat mempertahankan glukosa darahnya secara optimal dibandingkan mereka yang tidak memiliki kemampuan mengendalikan kadar glukosa darah dengan baik yang akan mengalami komplikasi seperti luka diabetik, penurunan penglihatan dan neuropati.. Tujuan dari penelitian ini adalah untuk mengetahui pengaruh program diabetes self management education terhadap penurunan kadar gula darah pada pasien DM tipe II. Metode penelitian ini menggunakan desain Quasy Experimental dengan menggunakan rancangan Non Equivalent Control Group dengan jumlah sampel 30 orang yang terdiri dari 15 responden kelompok intervensi dan 15 responden kelompok kontrol. Hasil penelitian ini menunjukan bahwa kelompok intervensi $p=0,001$ $(\mathrm{p}<0,05)$ dan kelompok kontrol $\mathrm{p}=0,007 \quad(\mathrm{p}<0,05)$ artinya ada pengaruh DSME terhadap penurunan kadar gula darah. Diharapkan program ini terus diterapkan dan dikembangkan di dalam praktik keperawatan di rumah sakit, puskesmas, dan instansi kesehatan lainnya.
\end{abstract}

Kata Kunci : Diabetes self management education ; Kadar gula darah

\section{PENDAHULUAN}

\section{Latar Belakang}

Menurut Depkes RI 2014 Diabetes melitus lebih dikenal dengan sebutan silent kiler menurut WHO diabetes merupakan penyakit tidak menular yang menyerang organ sehingga menimbulkan komplikasi seperti kebutaan, serangan jantung, stroke, gagal ginjal dan amputasi kaki. Hal ini membutuhkan kemampuan manajemen diri pasien dan pendidikan secara bekelanjutan (ADA,2016).

Berdasarkan data dari International Diabetes Federation (IDF) di tahun 2017, penderita diabetes melitus berjumlah 425 juta jiwa dan pada tahun 2045 diperkirakan akan meningkat sekitar 48\% dengan jumlah 629 juta jiwa penderita diabetes melitus. Di Asia Tenggara diperkirakan peningkatan prevalensi 151 juta jiwa penderita diabetes melitus di tahun 2045 dari 82 juta jiwa penderita diabetes melitus di tahun 2017 (IDF, 2017). Ditinjau dari hasil survei Organisasi Kesehatan Dunia (WHO) pada tahun 2015, jumlah penderita Diabetes Melitus di dunia sekitar 415 juta jiwa dari kenaikan 4 kali lipat dari 108 juta di tahun 1980an dan diprediksi jumlahnya akan meningkat sekitar 642 juta pada tahun 2040 sedangkan di Indonesia pada tahun 2015 menempati peringkat ke tujuh dunia untuk prevalensi diabetes tertinggi di dunia dan penyebab kematian tertinggi ketiga di Indonesia (WHO, 2016). 
Menurut Nuradhyani Diabetes melitus dapat menyebabkan komplikasi akut dan kronis yang disebabkan oleh meningkatnya kadar gula darah yang buruk dan penanganan yang tidak cepat dapat menimbulkan ketoasidosis diabetik, kerusakan microvaskuler, retinopati, nefropati dan neuropati yang mengakibatkan penurunan kualitas hidup pasien. Munculnya komplikasi pada penderita diabetes melitus akan menimbulkan beberapa macam keluhan dan memperbesar risiko prognosis yang buruk bagi penderita diabetes melitus (Lathifah, 2017).

Upaya mengendalikan kadar glukosa darah tetap dalam rentang normal dilakukan dengan pengaturan diet, exercise dan penggunaan insulin. Penderita yang merawat dirinya secara optimal dapat mempertahankan glukosa darahnya, dibandingkan dengan mereka yang tidak mampu mengendalikan kadar glukosa darah dengan baik, akan mengalami berbagai masalah seperti luka diabetik, penurunan penglihatan dan neuropati.

Pemberian edukasi merupakan pilar utama yang memiliki peranan penting dalam penatalaksanaan diabetes melitus meliputi tentang pemahaman perjalan penyakit diabetes melitus, pentingnya melakukan pengontrolan diabetes melitus, pentingnya mengetahui penyulit dan risiko serta penatalaksanaan farmakologis dan non-farmakologis diabetes melitus (Nuradhyani, dkk, 2017).

Bentuk edukasi yang telah terbukti keefektifannya dalam memberikan efek positif pada hasil klinis dan kualitas hidup pasien diabetes melitus tipe 2 adalah Diabetes Self Management Education (DSME). Menurut American Diabetes Association (ADA), Diabetes Self Management Education adalah proses untuk memfasilitasi pengetahuan pasien tentang manajemen diri dalam perawatan diri. Tujuan dari DSME adalah perilaku perawatan diri, pemecahan masalah, kolaboratif aktif dengan tim kesehatan untuk meningkatkan status kesehatan. (ADA, 2010).

Berbagai penelitian DSME yang telah dilakukan diantaranya, dilakukan oleh Rahmawati, dkk (2016) menunjukan hasil bahwa DSME dapat meningkatkan pengetahuan pasien diabetes melitus mulai dari pola makan, latihan fisik, kepatuhan menjalani pengobatan famakologis dan memonitoring kadar gula darah Peneliti juga telah melakukan survey awal di RSU. Royal Prima Medan dan data yang diperoleh jumlah penderita DM tipe 2 tiga bulan terakhir 141 orang dan peneliti telah melakukan wawancara kepada penderita DM tersebut tidak mengetahui cara manajemen diri terhadap pola makan, pola aktivitas, kepatuhan minum obat dan monitoring gula darah. Penelitian lain yang dilakukan oleh Wiastuti dkk, 2017 di dapatkan hasil bahwa adanya pengaruh DSME terhadap penurunan stress pada pasien DM tipe 2. Selain itu hasil peneliti lain yang telah membuktikan bahwa DSME dapat memberi pengaruh untuk memperbaiki hasil klinis pasien sehingga resiko ulkus diabetik menurun (Nuradhayani, 2017).

Berdasarkan data dan uraian diatas, serta dari hasil penelitian-penelitian yang dilakukan yang berkaitan dengan pengaruh edukasi terhadap pasien diabetes melitus, peneliti bermaksud meneliti pengaruh program Diabetes Self Management Education terhadap penurunan kadar gula darah pasien DM Tipe 2 di RSU Royal Prima Medan Tahun 2019.

\section{METODE PENELITIAN}

Jenis Penelitan dan Desain Penelitian 
Jenis peneliti ini adalah penelitian Quasy Experimental dengan menggunakan rancangan Non Equivalent Control Group yaitu penelitian yang dilakukan dengan dua kelompok tanpa randomisasi, satu kelompok diberi perlakuan dan kelompok kontrol, kemudian dievaluasi sebelum dan sesudahnya. Lokasi penelitian ini adalah di ruang rawat inap RSU. Royal Prima Medan, penelitian ini dilakukan pada tanggal 11 Juli sampai 13 Juli 2019.

\section{Populasi dan Sampel Penelitian}

Menurut Jiwantoro populasi merupakan kumpulan objek/subjek dalam suatu wilayah yang memiliki karakteristik dan kualitas berdasarkan keinginan peneliti untuk diteliti dan ditarik kesimpulan. Populasi dalam penelitian ini adalah seluruh pasien diabetes melitus tipe 2 yang berada di RSU. Royal Prima Medan berjumlah 141 orang.

Menurut Jiwantoro sample merupakan bagian dari populasi yang mewakili karakteristik. Teknik pengambilan sampel dalam penelitian ini adalah dengan menggunakan teknik purposive sampling yaitu teknik pengambilan sample sesuai keinginan peneliti berdasarkan kriteria inklusi dan eksklusi. Kriteria Inklusi pada penelitian ini adalah mampu melakukan aktivitas mandiri, mau bekerjasama selama penelitian, tidak mengalami kecacatan fisik dan mental. Sedangkan, kriteria eksklusi dari penelitian ini adalah pasien dengan daya ingat menurun serta pasien dengan gangguan penglihatan dan pendengaran, mengalami kecacatan fisik dan mental. Besarnya sampel pada penelitian ini adalah 30 orang yang terdiri dari 15 orang kelompok diberi edukasi dan 15 orang kelompok kontrol.

HASIL PENELITIAN DAN PEMBAHASAN

\section{Hasil Penelitian}

\section{Analisis Univariat}

Hasil penelitian yang dilakukan kepada responden di RSU. Royal Prima Medan 2019, mengenai pengaruh program diabetes selfmanagement education terhadap penuruanan kadar gula darah pada pasien diabetes melitus tipe 2, maka di dapat hasil sebagai berikut:

Tabel 3.1 Distribusi nilai kadar gula darah pasien DM tipe 2 sebelum pemberian program diabetes self management education (DSME) di RSU Royal Prima Medan Tahun 2019

\begin{tabular}{lcccc}
\hline Variabel & Intervensi Kontrol & $\begin{array}{c}\text { Jumlah } \\
\text { (n) }\end{array}$ & $\begin{array}{c}\text { Presentase } \\
(\mathbf{\%})\end{array}$ \\
\hline Kadar & & & & \\
Gula & & & & \\
Darah & & & & \\
a. Rendah & 1 & 1 & 2 & 6.7 \\
b. Normal & - & 3 & 3 & 10 \\
c. Tinggi & 14 & 11 & 25 & 83,3 \\
\hline Total & $\mathbf{1 5}$ & $\mathbf{1 5}$ & $\mathbf{3 0}$ & $\mathbf{1 0 0}$ \\
\hline
\end{tabular}

Pada tabel 3.1 dilihat berdasarkan variabel kadar gula darah pre test pada kelompok intervensi dan kontrol. Pada kelompok intervensi responden dengan kadar glukosa darah tinggi sebanyak 14 orang dan kadar glukosa darah rendah sebanyak 1 orang sedangkan pada kelompok kontrol responden dengan kadar glukosa darah tinggi sebanyak 11 orang, kadar glukosa darah rendah 3 orang dan kadar glukosa darah rendah 1 orang sehingga disimpulkan responden yang mayoritas kadar glukosa darah tinggi sebanyak 25 orang $(83,3 \%)$ dan minoritas responden dengan kadar glukosa darah normal sebanyak 3 orang (10\%) hingga KGD rendah sebanyak 2 orang $(6,7 \%)$.

Tabel 3.2 Distribusi nilai kadar gula darah pasien DM tipe 2 setelah pemberian program diabetes self management education (DSME) di RSU Royal Prima Medan

Tahun 2019

\begin{tabular}{lcc}
\hline Variabel Intervensi Kontrol Jumlah & $\begin{array}{c}\text { Presentase (\%) } \\
\text { (n) }\end{array}$ & \\
\hline $\begin{array}{l}\text { Kadar Gula } \\
\text { Darah }\end{array}$ & & \\
\hline
\end{tabular}




\begin{tabular}{lcccc} 
a. Rendah & & & & \\
b. Normal & 6 & 4 & 10 & 33,3 \\
c. Tinggi & 9 & 11 & 20 & 66,7 \\
\hline Total & $\mathbf{1 5}$ & $\mathbf{1 5}$ & $\mathbf{3 0}$ & $\mathbf{1 0 0}$ \\
\hline
\end{tabular}

Pada tabel 3.2 dilihat berasarkan variabel kadar gula darah post test pada kelompok intervensi dan kontrol. Pada kelompok intervensi responden dengan kadar glukosa darah tinggi sebanyak 9 orang dan kadar glukosa darah normal sebanyak 6 orang sedangkan pada kelompok kontrol responden dengan kadar glukosa darah tinggi sebanyak 11 orang dan kadar glukosa darah normal 4 orang sehingga disimpulkan responden yang mayoritas kadar glukosa darah tinggi sebanyak 20 orang $(66,7 \%)$ dan kadar glukosa darah normal sebanyak 10 orang $(33,3 \%)$.

\section{Analisis Bivariat}

Pada tahap ini dilakukan analisis untuk melihat perubahan nilai kadar gula darah sebelum dan sesudah dilakukan program Diabets Self Management Education dapat dilihat pada tabel berikut:

Tabel 3.3 Pengaruh Program Diabetes Self Management Education Terhadap Penurunan Kadar Gula Darah Pasien DM Tipe 2 Di RSU Royal Prima Medan Tahun 2019

\begin{tabular}{lccccc}
\hline Kelompok & N & Mean & SD & T & $\begin{array}{c}\text { p- } \\
\text { Value }\end{array}$ \\
\hline Intervensi & 15 & 87.667 & 82.001 & 4.141 & 0.001 \\
\hline Kontrol & 15 & 96.067 & 116.884 & 3.183 & 0.007 \\
\hline
\end{tabular}

Pada table 3.3 nilai KGD pasien DM tipe 2 pre post kelompok intervensi dan kelompok kontrol, menunjukkan ada perbedaan nilai selisih rata-rata kadar kadar glukosa darah pre dan post pada masingmasing kelompok. Kelompok intervensi menunjukan selisih rata-rata $87.67 \mathrm{mg} / \mathrm{dl}$ dengan standar deviasi 82,001 dan hasil t-score menunjukan kelompok intervensi memiliki nilai sebesar 4.141 dengan $p$ value $=0,001(<0,05)$. Sedangkan, rata-rata kadar glukosa darah pada kelompok kontrol sebesar 96,07 $\mathrm{mg} / \mathrm{dl}$ dengan standar deviasi 116.884 dan hasil tscore sebesar 3.183 dengan $\mathrm{p}$ value $=0,007$. Hal ini menunjukkan adanya perbedaan signifikan nilai KGD antara kelompok intervensi dan kelompok kontrol.

\section{Pembahasan}

Penelitian ini merupakan jenis penelitian kuantitatif menggunakan desain penelitian quasy experimental dengan rancangan non equivalent control group pada 30 responden yang telah terdiagnosis diabetes melitus tipe 2 dan tercatat di buku rekam medik RSU Royal Prima Medan. Responden dibagi dalam dua kelompok penelitian yaitu kelompok intervensi dengan 15 responden dan kelompok kontrol dengan 15 responden. Kelompok intervensi merupakan kelompok penelitian yang diberikan program Diabetes Self Management Education (DSME) dan leaflet DM sedangkan, kelompok kontrol merupakan kelompok penelitian yang tidak diberikan program diabetes self management education. Penelitian ini dilaksanakan selama 3 hari yaitu dimulai pada tanggal 11 Juli 2019 sampai 13 Juli 2019.

Hasil analisis data yang telah dilakukan pada 30 responden pada kedua kelompok penelitian yaitu kelompok intervensi dan kontrol akan diuraikan sebagai berikut :

Nilai kadar gula darah pada pasien diabetes melitus tipe 2 sebelum pemberian program diabetes self management education (DSME) di RSU Royal Prima Medan Tahun 2019

Berdasarkan hasil penelitian, nilai laboratorium kadar glukosa darah responden pada saat sebelum pemberian program diabetes self management education pada kedua kelompok penelitian menunjukkan kedua kelompok responden 
memiliki nilai kadar glukosa darah mayoritas tinggi sebanyak 25 orang (83,3\%), responden dengan kadar glukosa darah normal sebanyak 3 orang $(10 \%)$, dan responden dengan kadar glukosa darah rendah sebanyak 2 orang $(6,7 \%)$.

Hal ini sejalan dengan penelitian Nuradhayani, dkk (2017) menunjukkan bahwa tidak ada perbedaan yang signifikan antara nilai rata-rata peningkatan kadar glukosa darah responden pada kelompok intervensi dan kelompok kontrol sebelum pemberian DSME. Rata-rata kadar glukosa kelompok intervensi pada saat pre test adalah $265,45 \mathrm{mg} / \mathrm{dl}$ dengan standar deviasi 56,153 sedangkan pada kelompok kontrol rata-rata kadar glukosa darah pada saat pre test adalah $299,80 \mathrm{mg} / \mathrm{dl}$ dengan standar deviasi 92,985.

Menurut asumsi peneliti, tingginya nilai kadar glukosa darah pada pasien DM tipe 2 dikarenakan kurangnya pemahaman dan kesadaran pasien tentang strategi dalam perawatan mandiri dan mengoptimalkan kontrol metabolik untuk memperbaiki hasil klinis serta mencegah timbulnya komplikasi pada penyakit diabetes melitus tipe 2 . Kebiasaan yang paling sering dijumpai adalah pola diet yang tidak terkontrol, kurang menahan keinginan untuk makan dan minum yang manis, ketidakteraturan minum obat dan kurangnya aktivitas fisik selama perawatan penyakitnya sedangkan, pasien yang memiliki nilai kadar glukosa rendah dipengaruhi oleh kurangnya kesadaran diri pasien untuk memonitoring kadar glukosa darah secara rutin.

Nuradhayani (2017) mengatakan pola diet sangat berkaitan dengan terjadinya diabetes dan aktivitas fisik yang rendah memiliki risiko DM tipe 2 tiga kali lebih besar daripada yang melakukan aktifitas tinggi.perlunya kesadaran dan modivikasi gaya hidup seperti pengaturan diet DM, menghindari stres, dan aktivitas fisik yang rutin seperti senam diabetes sangat penting untuk dilakukan agar kestabilan glukosa darah pada pasien tetap terjaga dan terhindar komplikasi yang ditimbulkannya.

Nilai kadar gula darah pada pasien diabetes melitus tipe 2 setelah pemberian program diabetes self management education (DSME) di RSU Royal Prima Medan Tahun 2019

\section{Diabetes Self Management Education}

(DSME) merupakan salah satu cara untuk memfasilitasi pengetahuan, keterampilan dan kemampuan perawatan diri mandiri yang dibutuhkan oleh pasien DM tipe 2 (Dwipayanti, 2016). Untuk mencegah timbulnya komplikasi pada pasien diabetes melitus maka diperlukan pengontrolan secara teratur terhadap perubahan gaya hidup pasien DM dengan tepat. Pengontrolan diabetes melitus meliputi: pembatasan diet, peningkatan aktivitas fisik, pengobatan yang tepat, kontrol medis yang teratur dan pengontrolan metabolik melalui pemeriksaan laboratorium (Nuradhayani, 2017).

Hasil penelitian pada nilai laboratorium kadar glukosa darah pada pasien diabetes melitus tipe 2 setelah pemberian program diabetes self management education menunjukkan bahwa pada kelompok intervensi ada perubahan penurunan jumlah responden dengan nilai kadar glukosa darah tinggi sebanyak 9 orang dan ada peningkatan jumlah responden dengan nilai kadar glukosa darah normal sebanyak 6 orang dibandingkan pada kelompok kontrol responden dengan nilai kadar glukosa darah tinggi sebanyak 11 orang dan nilai kadar glukosa darah normal sebanyak 4 orang.

Menurut asumsi peneliti dengan pemberian edukasi manajemen diri pada pasien diabetes melitus akan meningkatkan pola pikir dan pengalaman yang 
baik terhadap perubahan gaya hidup kearah yang lebih sehat dan membentuk sikap positif sehingga perilaku mandiri menjadi lebih baik untuk meningkatkan kualitas hidupnya dibanding pasien yang tidak mendapatkan intervensi DSME. Hal ini ditunjukkan dengan sikap pasien yang mampu secara mandiri dalam pengelolaan diet dengan benar, mengurangi mengonsumsi makanan dan minuman yang manis, mengonsumsi obat secara teratur sesuai indikasi, mengatur pola istirahat dan aktivitas fisik, serta monitoring mandiri nilai kadar glukosa darah secara rutin.

Hal ini sejalan dengan penelitian Rahmawati, dkk (2016) tentang pengaruh program diabetes self management education terhadap manajemen diri pada penderita diabetes melitus tipe 2 menunjukkan hasil analisis uji statistik DSME berpengaruh terhadap pengetahuan $(\mathrm{p}=0.000)$, peningkatan pola makan $(\mathrm{p}=0.000)$, peningkatan latihan fisik $(\mathrm{p}=0.001)$, peningkatan farmakologis $(\mathrm{p}=0.000)$ dan peningkatan monitoring gula darah $(\mathrm{p}=0.000)$ pada pasien DM tipe 2 di Puskesmas Trienggadeng.

\section{Pengaruh Program Diabetes Self} Management Education terhadap penurunan kadar gula darah pasien DM tipe 2 di RSU Royal Prima Medan Tahun 2019.

Diabetes Self Management Education adalah proses untuk memfasilitasi pengetahuan pasien tentang manajemen diri dalam perawatan diri yang telah terbukti menurunkan kadar glukosa darah pada pasien diabetes melitus tipe 2 (ADA, 2010).

Hasil yang diperoleh berdasarkan uji statistik adalah adanya perbedaan nilai selisih ratarata kadar glukosa darah pre dan post pada kelompok intervensi menunjukan selisih $87.67 \mathrm{mg} / \mathrm{dl}$ dengan standar deviasi 82,001 dengan hasil t-score menunjukan nilai sebesar 4.141 dengan $\mathrm{p}$ value 0,001 $(<0,05)$ sedangkan kelompok kontrol selisih rata-rata kadar KGD sebesar 96,07 mg/dl dengan standar deviasi 116,884 dan hasil t-score menunjukkan nilai 3,183 dengan $p$ value $=0,007$. Hal ini menunjukkan adanya selisih yang signifikan terhadap penurunan kadar glukosa darah pada kelompok intervensi dibandingkan dengan kelompok kontrol artinya pemberian program diabetes self management education sangat berpengaruh terhadap penurunan kadar glukosa darah pada pasien diabetes melitus tipe 2.

Pemberian Diabetes Self Management Education berupa leafleat yaitu edukasi diabetes melitus, pengaturan pola diet, farmakologis, latihan fisik dan monitoring kadar glukosa darah diberikan sebanyak dua kali sehari selama tiga hari secara berkala.

Sesuai yang dikatakan Nuradhayani, dkk (2017) intervensi DSME dan pemberian leaflet DM mampu menahan laju kenaikan kadar glukosa pada penderita DM tipe 2 terbukti pada hasil penelitiannya menunjukkan perubahan yang signifikan terhadap penurunan kadar glukosa darah pada pasien diabetes melitus tipe 2 setelah pemberian program diabetes self management education dengan hasil uji statistik nilai $p=0.002(<0.005)$ dibandingkan dengan kelompok kontrol yang tidak mendapatkan diabetes self management education.

Hasil penelitian lain yang dilakukan oleh Rahmawati, dkk (2016) menunjukkan DSME sangat berpengaruh terhadap peningkatan pengetahuan $(p=0.000)$ dan peningkatan monitoring gula darah (0.000) pada pasien DM tipe 2 yang bermanfaat bagi pasien untuk mengontrol dan mengelola penyakit yang dialaminya. 
Menurut asumsi peneliti hasil dari proses pemberian program Diabetes Self Management Education (DSME) terbukti mempengaruhi penurunan kadar glukosa darah pada pasien diabetes melitus tipe 2 yang mana saat pemberian edukasi responden diberi pengetahuan tentang penyakitnya, mengajari cara mencegah laju keparahan penyakitnya yang kemudian mengajak dalam merencanakan pengelolaan terhadap penyakitnya. Informasi yang diberikan sangat mudah untuk dipahami dan diaplikasikan sehingga mendorong kemauan responden dalam melakukan tindakan pencegahan dan perawatan mandiri yang benar.

Hal ini sesuai dengan hasil penelitian Sudirman (2017) yang menyimpulkan adanya perbedaan self care diabetik pada pasien diabetes melitus tipe 2 sebelum dan sesudah penerapan Diabetes Self Management Education (DSME) metode kelompok pada kelompok intervensi dengan uji statistik $p$ value $=0.00$ dan menyatakan bahwa pemberian informasi kepada pasien mengenai panyakit dan cara perawatannya akan menunjukkan dampak positif terhadap kemampuan pengelolaan DM secara mandiri.

\section{KESIMPULAN DAN SARAN}

\section{Kesimpulan}

1. Berdasarkan hasil penelitian nilai kadar glukosa darah pada pasien DM tipe 2 sebelum pemberian program Diabetes Self Management Education (DSME) di RSU Royal Prima Medan Tahun 2019 menunjukkan mayoritas tinggi sebanyak 25 orang (83.3\%) dan nilai kadar glukosa normal sebanyak 3 orang $(10 \%)$.

2. Berdasarkan hasil penelitian nilai kadar glukosa darah pada pasien DM tipe 2 setelah pemberian program Diabetes Self Management Education (DSME) di RSU Royal Prima Medan Tahun 2019 menunjukkan mayoritas tinggi sebanyak 20 orang $(66.6 \%)$ dan nilai kadar glukosa darah normal sebanyak 10 orang (33.3\%).

3. Berdasarkan hasil uji paired T test menunjukkan adanya perbedaan signifikan antara nilai rata-rata kadar glukosa darah sebelum dan sesudah pemberian DSME kepada kelompok intervensi dan kelompok kontrol yang mana hasil t-score kelompok intervensi menunjukkan nilai sebesar 4.141 dengan $p=0.001(<0.005)$ sedangkan hasil t-score kelompok kontrol menunjukkan nilai 3.183 dengan $\mathrm{p}=0.007(<0.005)$ artinya ada pengaruh pemberian program diabetes self management education terhadap penurunan kadar glukosa darah pada pasien DM tipe 2 di RSU Royal Prima Medan Tahun 2019.

\section{Saran}

1. Disarankan kepada responden bahwa diabetes self management education (DSME) sangat bermanfaat untuk diterapkan di dalam keseharian dalam mengelola dan mengontrol penyakit yang dialaminya.

2. Disarankan kepada tenaga kesehatan khususnya perawat agar dapat mengaplikasikan program ini kepada pasien diabetes melitus tipe 2 untuk menambah wawasan dan kemampuan pasien dalam memanajemen diri terhadap penyakitnya sehingga selain meningkatkan kualitas hidup pasien juga meningkatkan efektifitas dan efesiensi kerja.

3. Disarankan kepada peneliti selanjutnya mengembangkan penelitian kuantitatif dengan desain lain yang terkait dengan pendidikan kesehatan pada penderita diabetes melitus tipe 2 dan mengikutsertakan keluarga.

\section{DAFTAR PUSTAKA}


ADA (American Diabetes Association). (2017). Standards Of Medical Care In Diabetes 2017. ISSN, 40 (1), 0149-5992.

Dwipayanti, Puteri Indah. (2016). Peningkatan Self Care Behaviour Pasien DM Tipe 2 Melalui Diabetes Self Management Education. Adi Husada Nursing Journa. 2 (2).

Fajriyah, Nuniek N. (2017). Hubungan Lama Sakit Diabetes Melitus dengan Pengetahuan Perawatan Kaki pada Pasien Diabetes Melitus Non Ulkus. URECOL. ISSN 2407-9189.

IDF (International Diabetes Federation). (2017). Diabetes Atlas. https://www.idf.org/aboutdiabetes/ what-is-diabetes/factsfigures.html

Jiwantoro Yudha Anggit, (2017). Riset Keperawatan. Mitra Wacana Media, Jakarta.

Lathifah. (2017). Hubungan Durasi Penyakit dan Kadar Gula Darah Dengan Keluhan Subyektif Penderita Diabetes Melitus. 5 (2), 231-239.

Nuradhayani, dkk. (2017). Pengaruh Diabetes Self Management Education (DSME) Terhadap Kadar Gula Darah Pasien Diabetes Type II di Balai Besar Laboratorium Kesehatan Makassar. Jurnal Ilmiah Kesehatan Diagnosis. 11 (4), eISSN: 2302-2531.

Nurkamillah, Novita, dkk. (2010). Pengaruh Diabetes Self Management Education and Support (DSME/S) Terhadap Diabetes Distress pada Pasien Diabetes Melitus Tipe 2 di RSD dr. Soebandi Jember. e-Jurnal Pustaka Kesehatan. 6 (1).

Rahayu, dkk. (2018). Faktor-faktor yang Berhubungan dengan Kadar Gula Darah pada Penderita Diabetes Melitus Tipe 2 (Studi di Wilayah Kerja Puskesmas Kedungmundu Kota Semarang. JKM (Jurnal Kesehatan Masyarakat). 6 (2), 2356-3346.

Rahmawati, dkk. (2016). Pengaruh Program Diabetes Self-Management Education
Terhadap Manajemen Diri Pada Penderita Diabetes Mellitus Tipe 2. ISSN, 4 (1), 2338-6371.

Ridwan, Arfiza, dkk. (2018). Efektivitas Diabetes Self Management Education Melalui SMS Terhadap Pengetahuan Penderita Diabetes Melitus: A Pilot Study. Idea Nursing Journal. 9 (1). ISSN: 2087-2879, e-ISSN: 2580-2445.

Rondhianto, (2012). Pengaruh Diabetes Self Management Education Dalam Discharge Planning Terhadap Self Care Behavior Pasien Diabetes Mellitus Tipe 2. Jurnal Kesehatan Soedirman. Vol. 7 No. (3).

Saputri, Sendika Widi, dkk. (2016). Studi Pengobatan Diabetes Melitus Tipe 2 dengan Komplikasi Hipertensi di Instalansi Rawat Jalan RSU dr. H. Koesnadi Bandowoso Periode Tahun 2014. e-Jurnal Pustaka Kesehatan. 4 (3), 479-483.

Sudirman, Andi Aktifa. (2017). Diabetes Melitus, Diabetes Self Management Education (DSME), and Self Care Diabetik. ISBN : 978-602-6204-10-3

WHO (World Health Organization). 2016. Diabetes Facts and Numbers Indonesian.https://www.8-whd2016diabetes-facts-and-numbersindonesian.pdf.html

Wiastuti, dkk. (2017). Pengaruh Diabetes Self Management Education and Support (DSME/S) Terhadap Stres Pada Pasien Diabetes Melitus (DM) Tipe 2 Di Wilayah Kerja Puskesmas Patrang Kabupaten Jember. e-Jurnal Pustaka Kesehatan, vol.5 (no.2). 